\title{
DETERMINATION OF NATURAL RADIONUCLIDE AND ASSESSMENTS OF HEALTH HAZARDS IN CHICKEN FEEDS AND MEAT CONSUMED IN LAGOS, NIGERIA
}

\author{
Ademola Augustine Kolapo ${ }^{1 a^{*}}$ and Gbadeyanka Afees ${ }^{2 a}$
}

aPhysical Sciences Department, Bells University of Technology. PMB1015, Ota, Ogun State, NIGERIA. Email: sirkay006@yahoo.com ${ }^{1}$; ade.gbadey@gmail.com²

*Corresponding author: akademola@bellsuniversity.edu.ng

Received: $25^{\text {th }}$ Mar $2020 \quad$ Accepted: $6^{\text {th }}$ Jan 2021

Published: 30 $0^{\text {th }}$ Jun 2021

DOI: https://doi.org/10.22452/mjs.vol40no2.5

\begin{abstract}
Poultry farming is a highly profitable and not capital intensive agricultural project. It is becoming one of the highest investments in agriculture in Nigeria. The proliferation of self -produced feeds by the Farmers with the addition of some minerals to stimulate growth could elevate the levels of radionuclides in feeds. This, therefore, calls for the determination of the health effects from the consumption of these chicken meats and organs. 10 samples of broilers and 30 feed samples (10 each of Starter, Grower, and Finisher feeds used in feeding the chicken) were used; collected from five selected poultry- farms in Lagos State, Nigeria, and analyzed using spectrometry analysis with $\mathrm{NaI}(\mathrm{Tl})$. The results obtained showed that concentrations of ${ }^{40} \mathrm{~K},{ }^{232} \mathrm{Th}$, and ${ }^{226} \mathrm{Ra}$ were $49.0 \pm 25.8,24.9 \pm 12.2$, and $32.9 \pm 16.2 \mathrm{Bqkg}^{-1}$ respectively, in chicken meats. In the feeds, their values were below the UNSCEAR recommendation. The annual effective doses in chicken meats and organs were lower than the $70 \mu \mathrm{Sv} / \mathrm{yr}$ limit. The cancer risk was within the recommended limit, and the internal hazard indices were below unity. The mean values of the transfer coefficient (TC) were also below 1 for ${ }^{40} \mathrm{~K}$, higher than unity for ${ }^{226} \mathrm{Ra}$ in Finisher feeds, and ${ }^{232} \mathrm{Th}$ in Starter feeds. The starter and finisher feeds were moderately contaminated. So, feeding chicken with these feeds may expose the consumers to the danger of over-exposure to ${ }^{226} \mathrm{Ra}$ and ${ }^{232} \mathrm{Th}$.
\end{abstract}

Keywords: Chicken Meat, Chicken feeds, Starter feeds, Finisher feeds, Grower feeds

\section{INTRODUCTION}

Natural radionuclides are present everywhere in the human environment and are released continuously into the ecosystem from natural and artificial sources (Anas et al., 2015). Studies on natural radioactivity revealed that natural radiation makes up about $85 \%$ of the radiation a person is exposed to during one year (WNA, 2016). Natural radioactive elements $(40 \mathrm{~K}, 232 \mathrm{Th}$, and 226Ra) and their concentrations depend on the local geology. Plants are grown on the soil, and they received nutrients from it through root uptake. Radioactive elements accumulate in plant tissues and may result in significant risk when ingested by man. Natural Occurring Radioactive Material (NORM) contaminates the human food chain through dust deposition, root absorption (transpiration), and fertilizer applications in agricultural practices. 
Poultry farming provides animal protein needed for growth and is fast becoming one of the highest investments in agriculture. In Nigeria, a significant fraction of the population is demanding chicken meat because it is white meat and has vital vitamins and essential metals (McDowell, 1992). These increasing demands made some farm-owners produce feeds on their own to make their birds grow faster. To this end, supplementary minerals were added to stimulate growth (Scheibel et al., 2006). Also, some feed produced from plants and animal sources (organic base) to give complete nutrition for the birds contains organic matter (Filho et al., 2016). These feeds may also contain natural radionuclides that may contaminate the poultry feeds (Ageda et al., 2017).

Many researchers had carried out researches in many parts of the world on poultry feeds and chicken meats. In Brazil, Filho et al., 2016, revealed a high level of ${ }^{40} \mathrm{~K}$ concentration in samples of poultry rations and dicalcium phosphate (DCP) used for cattle feed. Ageda et al., (2017) investigated the natural radionuclide levels in some Nigerian made poultry feedstuff and revealed that Nigerian poultry feeds have a relatively higher concentration of ${ }^{226} \mathrm{Ra}$ and ${ }^{232} \mathrm{Th}$. Amodu et al., 2018 determined the differences in activity concentration of ${ }^{40} \mathrm{~K}$, ${ }^{226} \mathrm{Ra}$, and ${ }^{232} \mathrm{Th}$ in free-range and cage type chicken meat in Ede, and Ilesha Osun State, southwestern Nigeria, and concluded that NORMs concentration was lower than the FAO dose limit. Ali et al., (2019) measured natural radioactivity in Chicken meat samples from Karbala Governate, Iraq, and found that concentrations of NORMs were lower than recommended values.

Broilers are reared for their flesh and were usually fed with fortified feeds to develop faster; therefore, there is the chance that they may contain a high concentration of radionuclides and long-term exposure or consumption of which may lead to cancer and other serious health risks (Mariam et al., 2004). For a healthy feed, it should be freed from harmful concentrations of toxic substances. Therefore, this study aims to evaluate natural radionuclides contents in chicken feeds and meat, estimate the hazards from the consumption of broiler, and the Transfer Coefficient (TC) from the three types of feed samples to chicken meat. This study will guide the populace on the accumulation of radionuclides from chicken meat and add to knowledge in the protection of the public from hazardous substances in food products.

\section{MATERIALS AND METHODOLOGY}

The study area is Lagos, situated on longitude $6.5244 \mathrm{o} \mathrm{N}$ to latitude $3.3792 \mathrm{o} \mathrm{E}$ with a population of 21 million (NPC, 2016). Lagos is mainly cosmopolitan; however, agricultural practices are being carried out in some mainlands areas used for this study. Large-scale poultry farming areas in Lagos are Ogba, Agege, Ikeja, Iyana-Ipaja, and Mushin areas. These sites were chosen for this research and will be represented as Ogba (A); Agege (B); Ikeja (C); Iyana-Ipaja (D), and Mushin (E)

\subsection{Collection and Preparation of samples}

Broiler chickens were purchased from five selected poultry farms used for this study; two chicken samples from each poultry farm. The chickens were killed, defeathered, and washed. The chicken samples were oven-dried at a temperature of $378 \mathrm{~K}$ to constant weight (Amodu et al., 2018). The dried samples were mashed and pulverized to 
fine form and sieved. The pulverized samples were packed with identification labels and taken to the laboratory. One hundred and fifty gram $(150 \mathrm{~g})$ of the pulverized chicken sample was weighed into an uncontaminated cylindrical synthetic container, properly labelled to avoid mix up and hermetically sealed for thirty days (Veiga et al., 2006) for secular equilibrium between $238 \mathrm{U}$ (226Ra) and 232Th (228Ra) and their respective progenies before measurement. Also, two samples of each of the three types of chicken feeds were collected. The feed samples were dried at room temperature in the laboratory, stones and any other particles were removed. The feed samples were crushed and sieved through a $2 \mathrm{~mm}$ sieve size. One hundred and fifty grams of fine particulates were weighed and transferred into a cylindrical plastic container and hermetically sealed for thirty days for secular equilibrium (Veiga et al., 2006).

\subsection{Determination of radionuclides activity in the samples}

Chicken and feed samples were analyzed using a detector system consisting of a NaI (Tl) crystal coupled to an ORTEC
Multichannel analyzer manufactured by ORTEC Inc, South Carolina, USA. For data acquisition and processing, the PC spectrum acquisition and analysis software MAESTRO-32 was used. A lead of about 5 $\mathrm{cm}$ was used to shield the detector, away from background radiation. The resolution of the detector was about $8 \%$ at $0.662 \mathrm{MeV}$ of 137Cs. Energy and efficiency calibrations were performed with standard and certified reference materials prepared by the International Atomic Energy Agency (IAEA), Vienna. A linear graph was drawn from the gamma energy and the corresponding channel number, as shown in Figure 1. The coefficient of determination obtained $\left(R^{2}=0.9951\right)$ was stored in the MCA for measurement and calculation. Three regions of interest were created for this work. The photopeak corresponding to gamma energy of $1.465 \mathrm{MeV}$ was used for ${ }^{40} \mathrm{~K}$. The photopeak energy of $1.765 \mathrm{MeV}$ was used to determine ${ }^{238} \mathrm{U}$, while ${ }^{232} \mathrm{Th}$ was determined from the energy of photo 2.615 $\mathrm{MeV}$. Energy peaks were obtained from the regions of interest (ROI) created in the neighborhood of observed energy. The samples were counted for 36,000 seconds each.

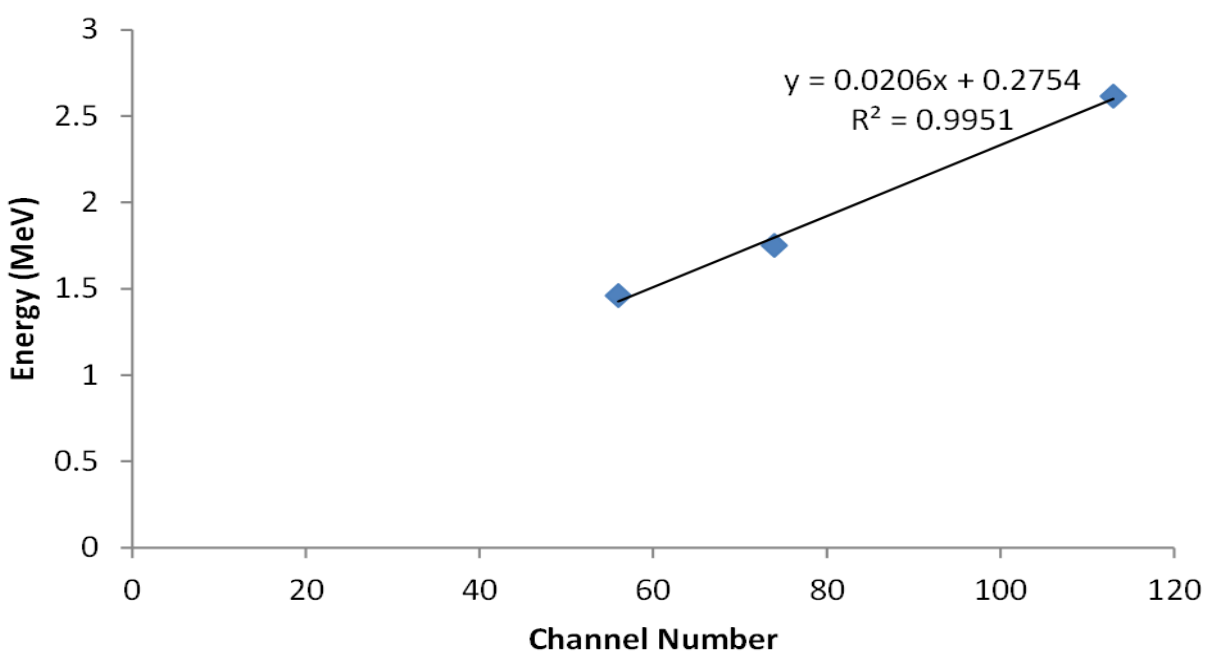

Figure 1. Energy calibration curve. 


\section{RESULTS AND DISCUSSION}

\subsection{Radionuclide concentrations}

The concentrations of the natural radionuclide obtained in the samples are in Table 1. In the ten chicken meat samples, the activity of ${ }^{40} \mathrm{~K}$ was found to be lower than 400 $\mathrm{Bqkg}^{-1}$ set by (UNSCEAR, 2000). Radium level was high in site A $\left(43.5 \pm 4.2 \mathrm{Bqkg}^{-1}\right)$ but lower in other sites $(\mathrm{B}-\mathrm{E})$. 232Th concentration ranged from $14.0 \pm 3.8 \mathrm{Bqkg}^{-1}$ to $54.8 \pm 3.1 \mathrm{Bqkg}^{-1}$ with a mean of $32.9 \pm 16.2$ $\mathrm{Bqkg}^{-1}$. The concentrations of ${ }^{40} \mathrm{~K}$ in the starter feed were within the world average in all the samples. Its concentration ranged from $59.8 \pm 13.2$ to $90.8 \pm 12.1 \mathrm{Bqkg}^{-1}$ with a mean concentration of $76.8 \pm 11.7 \mathrm{Bqkg}^{-1}$. There was a higher concentration of ${ }^{226} \mathrm{Ra}$ in Site $\mathrm{D}$, and $\mathrm{E}$ than the world recommended value but lower in other sites $(\mathrm{A}, \mathrm{B}, \mathrm{C})$ with a mean concentration of $29.4 \pm 9.1 \mathrm{Bqkg}^{-1}$. Also, a higher concentration of ${ }^{232} \mathrm{Th}$ was obtained in Site B $(65.0 \pm 16.2)$ with a mean concentration of $35.4 \pm 17.3$ Bqkg-1.

In Grower feeds, the mean concentrations were $80.7 \pm 10.6,28.4 \pm 9.2$, and $39.7 \pm 8.8 \mathrm{Bqkg}-1$ respectively, for ${ }^{40} \mathrm{~K},{ }^{226} \mathrm{Ra}$, and ${ }^{232} \mathrm{Th}$, while in Finisher feeds, the means were $72.6 \pm 19.7,25.3 \pm 10.9$, and 35.0 \pm 9.9 $\mathrm{Bqkg}^{-1}$, respectively. Higher concentrations of ${ }^{226} \mathrm{Ra}$ greater than the recommended world average were recorded in Grower feeds from Site D $(42.0 \pm 10.2)$ and $232 \mathrm{Th}$ concentration in Site A $(53.5 \pm 11.0)$. In finisher feeds, a higher concentration of ${ }^{226} \mathrm{Ra}$ was also recorded in Site A (40.5 \pm 9.4$)$. A comparison of natural radionuclides estimated in the feeds is in Figure 2. The concentration of ${ }^{40} \mathrm{~K}$ was the highest in all the sites while the concentration of ${ }^{226} \mathrm{Ra}$ was lowest; highest in Finisher feeds from site $\mathrm{A}$ and lowest in Grower feeds from site E. The maximum concentration of ${ }^{232} \mathrm{Th}$ in the feed samples was from the starter feed (site B), and the minimum is from finisher feeds (site B).

Table 1. Concentration of radionuclide in Chicken meat and the feed samples in the five poultry farms $\left(\mathrm{Bq} \mathrm{kg}^{-1}\right)$

\begin{tabular}{|c|c|c|c|c|c|c|c|c|c|c|c|c|}
\hline \multirow{3}{*}{ Samples } & \multirow{2}{*}{\multicolumn{3}{|c|}{ Chicken Meat }} & \multicolumn{9}{|c|}{ Chicken Feeds } \\
\hline & & & & \multicolumn{3}{|c|}{ Starter } & \multicolumn{3}{|c|}{ Grower } & \multicolumn{3}{|c|}{ Finisher } \\
\hline & ${ }^{40} \mathrm{~K}$ & ${ }^{226} \mathrm{R}$ & ${ }^{232} \mathrm{~T}$ & ${ }^{40} \mathrm{~K}$ & ${ }^{226} \mathrm{R}$ & ${ }^{232} \mathrm{~T}$ & ${ }^{40} \mathrm{~K}$ & ${ }^{226} \mathrm{R}$ & ${ }^{232} \mathrm{~T}$ & ${ }^{40} \mathrm{~K}$ & ${ }^{226} \mathrm{R}$ & ${ }^{232} \mathrm{~T}$ \\
\hline & & $\mathrm{a}$ & $\mathrm{h}$ & & $\mathrm{a}$ & $\mathrm{h}$ & & $\mathrm{a}$ & $\mathrm{h}$ & & $\mathrm{a}$ & $\mathrm{h}$ \\
\hline \multirow[t]{2}{*}{ Site A } & 82.1 & 43.5 & 54.8 & 75.3 & 25.4 & 30.4 & 93.2 & 28.1 & 53.5 & 101. & 42.5 & 42.5 \\
\hline & $\begin{array}{l} \pm 10 \\
1\end{array}$ & \pm 4.2 & \pm 3.1 & $\begin{array}{l} \pm 12 \text {. } \\
1\end{array}$ & \pm 7.2 & \pm 5.6 & $\begin{array}{l} \pm 41 . \\
2\end{array}$ & \pm 5.3 & $\begin{array}{l} \pm 11 . \\
0\end{array}$ & $\begin{array}{l}5 \pm 15 \\
4\end{array}$ & \pm 9.4 & $\begin{array}{l} \pm 16 . \\
0\end{array}$ \\
\hline \multirow[t]{2}{*}{ Site B } & 38.7 & 26.5 & 38.9 & 59.8 & 22.5 & 65.0 & 72.9 & 29.0 & 37.5 & 62.7 & 18.9 & 17.7 \\
\hline & \pm 8.6 & \pm 4.1 & \pm 3.5 & $\begin{array}{l} \pm 13 . \\
2\end{array}$ & \pm 8.2 & $\begin{array}{l} \pm 16 \text {. } \\
2\end{array}$ & $\begin{array}{l} \pm 15 . \\
3\end{array}$ & \pm 9.2 & \pm 6.5 & $\begin{array}{l} \pm 10 . \\
5\end{array}$ & \pm 3.2 & \pm 3.5 \\
\hline \multirow[t]{2}{*}{ Site C } & 27.7 & 12.7 & 20.3 & 90.8 & 21.1 & 25.6 & 89.1 & 27.1 & 37.1 & 52.0 & 18.4 & 36.5 \\
\hline & $\begin{array}{l} \pm 11 \text {. } \\
1\end{array}$ & \pm 3.2 & \pm 4.5 & $\begin{array}{l} \pm 12 . \\
1\end{array}$ & \pm 4.2 & \pm 8.2 & $\begin{array}{l} \pm 21 . \\
7\end{array}$ & \pm 7.8 & \pm 4.2 & $\begin{array}{l} \pm 11 \text {. } \\
2\end{array}$ & \pm 4.3 & $\begin{array}{l} \pm 10 . \\
7\end{array}$ \\
\hline \multirow[t]{2}{*}{ Site D } & 70.4 & 26.9 & 36.4 & 73.9 & 37.3 & 21.1 & 68.1 & 42.0 & 29.4 & 83.0 & 29.7 & 39.0 \\
\hline & $\begin{array}{l} \pm 19 . \\
2\end{array}$ & \pm 5.2 & \pm 6.1 & $\begin{array}{l} \pm 22 \text {. } \\
1\end{array}$ & $\begin{array}{l} \pm 13 . \\
0\end{array}$ & \pm 3.4 & $\begin{array}{l} \pm 18 . \\
0\end{array}$ & $\begin{array}{l} \pm 10 . \\
2\end{array}$ & \pm 6.8 & $\begin{array}{l} \pm 12 . \\
8\end{array}$ & \pm 4.9 & \pm 8.6 \\
\hline
\end{tabular}




\begin{tabular}{lllllllllllll} 
Site E & 26.2 & 15.1 & 14.0 & 84.1 & 41.0 & 35.1 & 80.1 & 16.0 & 40.8 & 63.6 & 17.0 & 39.4 \\
& \pm 6.3 & \pm 3.1 & \pm 3.8 & \pm 13. & \pm 12. & \pm 11. & \pm 18. & \pm 4.2 & \pm 11. & \pm 21. & \pm 6.7 & \pm 14. \\
& & & & 2 & 4 & 2 & 6 & & 3 & 1 & & 2 \\
Mean & 49.0 & 24.9 & 32.9 & 76.8 & 29.4 & 35.4 & 80.7 & 28.4 & 39.7 & 72.6 & 25.3 & 35.0 \\
& \pm 25. & \pm 12. & \pm 16. & \pm 11. & \pm 9.1 & \pm 17. & \pm 10. & \pm 9.2 & \pm 8.8 & \pm 19. & \pm 10. & \pm 9.9 \\
& 8 & 2 & 2 & 7 & & 3 & 6 & & & 7 & 9 & \\
\hline
\end{tabular}

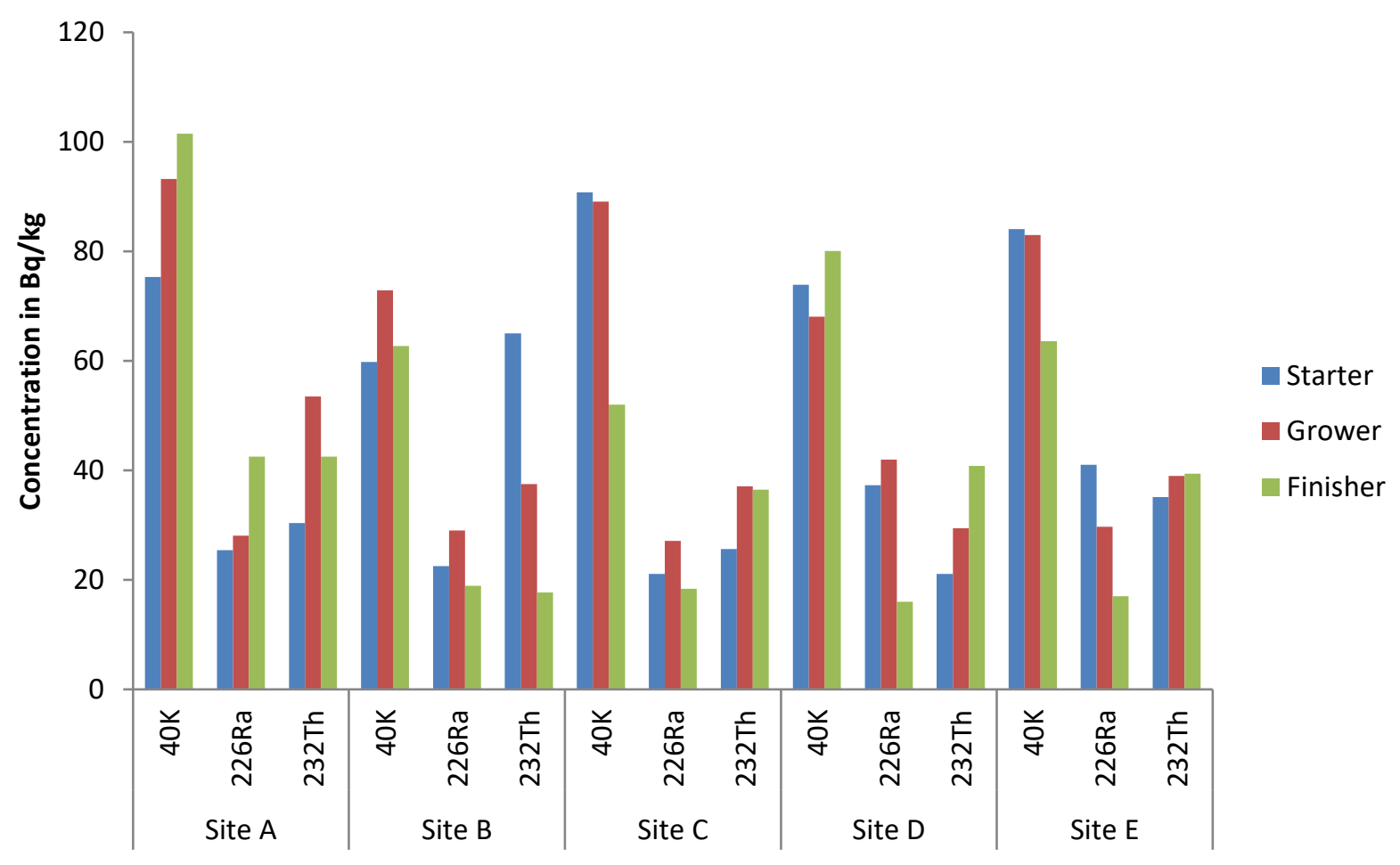

Figure 2. Comparison of radionuclide concentrations in starter, grower, and finisher feeds in the study sites

3.2 Calculation of Radiation Hazard from Consumption of Broiler.

\subsubsection{Effective dose from ingestion of}

$$
\mathrm{E}_{\text {dose }}=\mathrm{DCF}_{\text {ing }} \times \mathrm{I}_{\mathrm{p}} \times \mathrm{A}_{\mathrm{SP}}
$$

Where $\mathrm{DCF}_{\text {ing }}$ is the dose conversion factor for ingestion for each radionuclide. According

\section{chicken meat.}

The annual effective dose was calculated using equation 1. to UNSCEAR, 2000, 226Ra has the conversion factor of $2.8 \times 10-7 \mathrm{~Sv} / \mathrm{Bq} ; 232 \mathrm{Th}$ 
has $2.3 \times 10-7 \mathrm{~Sv} / \mathrm{Bq}$, and $40 \mathrm{~K}$ has $6.2 \times 10-$ $9 \mathrm{~Sv} / \mathrm{Bq}$ for adults. The consumption rate for the intake of NORMs in chicken meat (a rate of $8.8 \mathrm{~kg} /$ year for the chicken flesh in Nigeria is taken from (FAO, 2010). Asp is the specific activity concentration in the broiler chicken samples.

The results obtained are presented in Table 2 and were lower than the recommended dose limit (FAO 2010) in all the samples analyzed.

\subsubsection{Probable Cancer risk from ingestion of Broiler}

The consumption of radionuclides from the Broiler chicken may have some adverse health effects on the consumers; the likely health effect is cancer. The probability of having cancer from the consumption of broiler was calculated and termed cancer risk as stated in the equation below.

$$
\text { Cancer Risk }=\mathrm{E}_{\text {Dose }} \mathrm{X} \mathrm{LE}_{\mathrm{E}} \mathrm{X} \mathrm{RF}
$$

Where EDose is the effective dose in $(\mu \mathrm{Sv} / \mathrm{y})$, LE is the life span for the Nigerian population (55 years) (WHO, 2020), and RF is the conversion factor $(\mathrm{Sv}-1)$ taken as 0.05 for the public (ICRP, 1991). The estimated value is in Table 2. The results obtained were within $1 \times 10-6-1 \times 10-4$ recommendation (WHO, 2007).

\subsubsection{Internal Risk Index}

Internal Risk Index (Hint) is the internal exposure of respiratory organs by radon and its progeny. It is calculated using equation 3 (Berekta and Mathew, 1985). The results obtained are presented in Table 2.

$$
H_{\mathrm{int}}=\frac{A_{R a}}{159}+\frac{A_{T h}}{259}+\frac{A_{K}}{4810}<1
$$

The results showed that the Internal Risk desirable range. Indices in all the sites studied were within the

Table 2. Annual Effective dose in chicken meat from the five poultry farms

\begin{tabular}{cccc}
\hline Samples & Effective dose $(\mu \mathrm{Sv} / \mathrm{y})$ & Probable Cancer Risk $\left(\mathrm{x} 10^{-4}\right)$ & Internal Hazard Index $\left(\mathrm{H}_{\text {int }}\right)$ \\
\hline Site A & 222.9 & 0.67 & 0.50 \\
Site B & 146.2 & 0.44 & 0.33 \\
Site C & 74.8 & 0.23 & 0.22 \\
Site D & 144.3 & 0.43 & 0.32 \\
Site E & 67.2 & 0.20 & 0.15 \\
Mean & $\mathbf{1 3 1 . 1}$ & $\mathbf{0 . 4 0}$ & $\mathbf{0 . 3 0}$ \\
\hline
\end{tabular}


The concentration of radionuclides obtained in this study was compared with other studies found in the literature and are presented in Table 3 . The ${ }^{40} \mathrm{~K}$ concentration obtained is similar to what was obtained in Egypt (Harb et al., 2010) but higher for ${ }^{226} \mathrm{Ra}$ and ${ }^{232} \mathrm{Th}$. In Brazil, a higher concentration of ${ }^{40} \mathrm{~K}$ was reported in poultry feeds (Filho et al., 2016). Similarly, a higher concentration of ${ }^{40} \mathrm{~K}$ than the present study was reported in Benue and Kaduna states, Nigeria (Ageda et $a l ., 2017)$. Despite the higher concentration of ${ }^{226} \mathrm{Ra}$ and ${ }^{232} \mathrm{Th}$ in this study, their concentrations were below UNSCEAR, 2000 recommended values. Radionuclides concentrations in chicken flesh were also compared with other studies and are presented in Table 3. The level of ${ }^{40} \mathrm{~K}$ obtained in this study is higher than what was obtained in Nigeria (Amodu et al., 2018) and Iraq (Ali et al., 2019). The levels obtained for ${ }^{226} \mathrm{Ra}$ and ${ }^{232} \mathrm{Th}$ were higher than what was obtained in Iraq (Ali et al., 2009) but lower than those obtained in Nigeria (Amodu et al., 2018).

Table 3. Comparison of radionuclide results with others in the literature.

\begin{tabular}{|c|c|c|c|c|c|c|c|c|c|}
\hline \multirow{2}{*}{ Country } & \multirow{2}{*}{ References } & \multicolumn{3}{|c|}{ Chicken feed } & \multirow{2}{*}{ Country } & \multirow{2}{*}{ References } & \multicolumn{3}{|c|}{ Chicken Meat } \\
\hline & & ${ }^{40} \mathrm{~K}$ & ${ }^{226} \mathrm{Ra}$ & ${ }^{232} \mathrm{Th}$ & & & ${ }^{40} \mathrm{~K}$ & ${ }^{226} \mathrm{Ra}$ & ${ }^{232} \mathrm{Th}$ \\
\hline Egypt & $\begin{array}{c}\text { (Harb et } \\
\text { al., 2010) }\end{array}$ & $\begin{array}{l}60.5- \\
91.2\end{array}$ & $\begin{array}{c}0.35- \\
1.17\end{array}$ & $\begin{array}{c}0.27- \\
1.07\end{array}$ & Nigeria & $\begin{array}{l}\text { Amodu et } \\
\text { al., } 2018\end{array}$ & 37.8 & 72.5 & 49.1 \\
\hline Brazil & $\begin{array}{c}\text { (Filho et } \\
\text { al., 2016) }\end{array}$ & $\begin{array}{l}236- \\
402\end{array}$ & $\begin{array}{c}0.23- \\
1.51\end{array}$ & $\begin{array}{c}0.29- \\
1.63\end{array}$ & Iraq & $\begin{array}{c}\text { Ali et al., } \\
2019\end{array}$ & 14.27 & 2.26 & 1.3 \\
\hline $\begin{array}{l}\text { Nigeria } \\
\text { (Benue } \\
\text { and } \\
\text { Kaduna) }\end{array}$ & $\begin{array}{l}\text { (Ageda et } \\
\text { al., 2017)] }\end{array}$ & $\begin{array}{l}43.6- \\
196.8\end{array}$ & $\begin{array}{l}5.0- \\
34.7\end{array}$ & $\begin{array}{l}0.9- \\
51.6\end{array}$ & $\begin{array}{c}\text { Present } \\
\text { Study } \\
\text { (Lagos, } \\
\text { Nigeria) }\end{array}$ & & 49 & 24.9 & 32.9 \\
\hline \multirow{3}{*}{$\begin{array}{c}\text { Present } \\
\text { Study } \\
\text { (Lagos, } \\
\text { Nigeria) }\end{array}$} & Starter & $\begin{array}{c}59.8- \\
90.8\end{array}$ & $\begin{array}{l}21.1- \\
41.0\end{array}$ & $\begin{array}{c}21.1- \\
65.0\end{array}$ & & & & & \\
\hline & Grower & $\begin{array}{l}68.1- \\
93.2\end{array}$ & $\begin{array}{l}16.0- \\
42.0\end{array}$ & $\begin{array}{c}29.4- \\
53.5\end{array}$ & & & & & \\
\hline & Finisher & $\begin{array}{l}52.0- \\
101.5\end{array}$ & $\begin{array}{l}17.0- \\
42.5\end{array}$ & $\begin{array}{c}17.7- \\
42.5\end{array}$ & & & & & \\
\hline
\end{tabular}

\subsection{Transfer Coefficient}

Transfer Coefficient of radionuclides from the feed samples to the chicken samples was estimated to have an approximate quantity of radionuclides transferred into the chicken meat that humans consume. This Transfer Coefficient (TC) was calculated from 
measured radionuclides in the chicken feeds and the corresponding chicken meat; the transfer coefficient was estimated from equation 4 (Chibowski and Gladdysz, 1999).

$$
\text { Transfer Coefficient }(\mathrm{TC})=\frac{\text { Activity concentration in chicken me }\left(B q K g^{-1}\right)}{\text { Activity concentration in chicken feeds }\left(B q K g^{-1}\right)}
$$

The transfer coefficient (TC) of radionuclides in the feed samples is presented in Table 4. The transfer coefficient of ${ }^{40} \mathrm{~K}$ was obtained to be higher than one in Starter and Grower feeds, especially from Site A and D. Elsewhere, TC was lower than one. This means that chicken meats from sites (A and D) were moderately contaminated with ${ }^{40} \mathrm{~K}$. The transfer coefficient of ${ }^{226} \mathrm{Ra}$ was also higher than one in Starter feeds from Site A and B; in Grower feeds from Site A and in Finisher feeds from Sites A, B and C. So also was the transfer coefficient of ${ }^{232} \mathrm{Th}$ in Starter feeds from Site A; Grower feeds from Sites A, B, and D; and Finisher feeds from Site A and B. Therefore, the chicken's meats from these sites were moderately contaminated with radionuclides.

Table 4. Transfer Coefficient (TC) of radionuclides from chicken feeds to chicken meat in the 3 feeds in the five sites

\begin{tabular}{cccccccccc}
\hline Samples & \multicolumn{3}{c}{ Starter } & \multicolumn{3}{c}{ Grower } & \multicolumn{3}{c}{ Finisher } \\
\hline & ${ }^{40} \mathrm{~K}$ & ${ }^{226} \mathrm{Ra}$ & ${ }^{232} \mathrm{Th}$ & ${ }^{40} \mathrm{~K}$ & ${ }^{226} \mathrm{Ra}$ & ${ }^{232} \mathrm{Th}$ & ${ }^{40} \mathrm{~K}$ & ${ }^{226} \mathrm{Ra}$ & ${ }^{232} \mathrm{Th}$ \\
Site A & 1.09 & 1.71 & 1.80 & 0.88 & 1.55 & 1.02 & 0.80 & 1.02 & 1.30 \\
Site B & 0.65 & 1.17 & 0.59 & 0.53 & 0.91 & 1.03 & 0.62 & 1.41 & 1.09 \\
Site C & 0.30 & 0.60 & 0.79 & 0.31 & 0.93 & 0.55 & 0.53 & 1.38 & 0.56 \\
Site D & 0.95 & 0.72 & 1.72 & 1.03 & 0.64 & 1.24 & 0.84 & 0.90 & 0.93 \\
Site E & 0.31 & 0.34 & 0.42 & 0.33 & 0.94 & 0.34 & 0.41 & 0.89 & 0.35 \\
Average & 0.66 & 0.91 & 1.06 & 0.62 & 0.99 & 0.84 & 0.64 & 1.12 & 0.85 \\
\hline
\end{tabular}

\section{CONCLUSION}

The radionuclide contents of chicken meat and chicken feed (Starter, Grower, and Finisher) in some poultry farms in Lagos state were determined using spectrometry method. Results obtained from the chicken meat and chicken feed analyses showed that $40 \mathrm{~K}$ was detected in a significant amount while other naturally occurring radionuclides were in minimal concentrations. The high concentration of $40 \mathrm{~K}$ may be connected to the plants used in the production of the feeds, which had been contaminated from fertilizer and manure in their cultivation. The ranges of concentrations of radionuclides in the samples were within the recommended value (UNSCEAR, 2000). The study of the transfer of radionuclides from chicken feeds to chicken meat showed that the TC of radionuclides was higher than unity for $232 \mathrm{Th}$ in Starter feeds and 226Ra in Finisher feeds meaning that the concentrations of 232Th and $226 \mathrm{Ra}$ were the major contributor to the effective dose from the feeds. Therefore, farmers should be careful feeding broilers with starter and finisher feed which may expose both poultry and the consumers to an 
elevated level of 226Ra and 232Th, which in the long-term may cause several health effects in the poultry and the consumers.

\section{REFERENCES}

Ageda, VI, Ikee, EE, and Temaugee, ST. (2017). Assessment of natural radionuclide level in some Nigeria made poultry feedstuff. International Journal of Physical Sciences. 12 (19):243-6.

Ali, AR, Nadhim, KI, Auras, MO, and Nada FK. (2009). Measurement of the Natural Radioactivity in Chicken meat samples from Karbala Governate, Iraq. World Sci. News 117:196-203.

Amodu, FR.; Ben, F.; Giwa, KW.; Ayinde, SA.; Ugwu, NU.(2018). Radiological comparative analysis of differently reared chicken meat from gold mining and non-gold mining corridors. J. Rad. Nucl.Appl 3(1): 33-38.

Anas, MS.; Abdullahi, S; Yusuf, JA.; Bala, B.; Salihu, YB. (2015). Assessment of toxic elements in some selected Nigeria broiler feeds using Neutron Activation Analysis. Bayero $J$. Pure\&Appli. Sci.: 166-9.

Berekta, J and Mathew, PJ (1985). Natural Radioactivity in Australian building materials, industrial wastes, and byproduct, Health Phys, 48:87-95.

Chibowski, S. and Gładysz, A (1999). Examination of radioactive contamination in the soil-to-plant system and their transfer to selected animal tissues. Pol. J. Environ Stud 8(1):19-23.
(FAO, 2010). Food and Agriculture Organization. Statistical database of the Food and Agriculture Organization of the United Nations. Methods and Standards. http://faostat3.fao.org/mes/ methodology_list/E

Filho, IVL, Scheibel, V, Appoloni, CR (2016). Potassium-40, Radium-226 and Radium-228 series in Bovine and poultry Feed and Di-calcium Phosphate (DCP) Samples by GammaRay Spectrometry. Braz. Arch. Biol. Technol. 59:1678-4324.

Harb, SK. Sahalel, KD, Abbady, A., and Nagwa S. (2010). The annual dose for the Qena governorate population due to the consumption of animal products. Proceeding of the 4th Environmental physics Conference, 10-14th March, Hurghada, Egypt:37-45.

(ICRP, 1991). International Commission on Radiological Protection. Recommendations of the ICRP. Publication 60, Annals of the ICRP, 21(1-3).

(ICRP, 2007). International Commission on Radiological Protection. Recommendation of the ICRP. Publication 103. Annals of the ICRP, 37(2-4).

Mariam, I, Iqbal, S and Nagra, AS (2004). Distribution of some trace macro minerals in beef, mutton and poultry. Inter J. Agric. Biol. 6(5):816-20. 1560-8530/2004/06-5-816-820.

McDowell LR. Minerals in Animal and Human Nutrition: Comparative Aspects to Human Nutrition. 2nd ed. 
Academic Press Inc. San Diego, USA; c1992. 660p.

(NPC, 2016) National Population Commission of Nigeria. National Population Commission and National Bureau of Statistics Estimates. Available at https://www.nigerianstat.gov.ng/

Scheibel, V, Appoloni, CR, Schechter, H (2006). Natural radioactivity traces in South-Brazilian cereal flours by gamma-ray spectrometry. $J$. Radioanal Nucl Chem.270(1):163-5

(UNSCEAR, 2000) United Nations Scientific Committee on the Effects of Atomic Radiation Sources and effects of ionizing radiation. Report to the General Assembly, Annexe B, Vol1:p93-96.

Veiga, R, Sanches, N, Anjos, RM, Macario, K, Bastos, J, Iguatemy, M, Aguiar, JG,
Santos, AMA, Mosquera, B, Carvalho, C, Baptista, Filho M.B, Umisedo, NK (2006). Measurement of natural radioactivity in Brazilian beach sands. Radiat Meas. 41: 189-196

World Health Organization (2007). Guidelines for assessing the quality of herbal medicines with reference to contaminants and residues. Geneva [Cited 2020, January 15] Available from apps.

WHO.int/iris/handle/10665/43510

World Health Organization (2020). Nigeria Life Expectancy 1950-2020 | Macro Trends. [Cited 2020 January 15]. Available from www.microtrends.net

World Nuclear Association. (2016). Nuclear radiation and health effects. [Cited 2020 January, 20]. Available online from HTTP// www.worldnuclear.Org/. 